\title{
Three cultivars of Lablab purpureus foliage in Igbo-Ora, Oyo State, Nigeria are
} nutritive

\author{
${ }^{1}$ Alalade, J. A., ${ }^{2}$ Akinlade, J. A., ${ }^{3}$ Fajemisin, A. N. and Adebisi, I. A ${ }^{1}$ \\ ${ }^{I}$ Department of Animal Health and Production, Oyo State College of Agriculture and \\ Technology, P.M.B. 10, Igbo Ora.Oyo State. \\ ${ }^{2}$ Department of Animal Production and Health, LadokeAkintola University of \\ Technology, P.M.B.4000,Ogbomoso, Oyo State. Nigeria. \\ ${ }^{3}$ Department of Animal Production and Health,

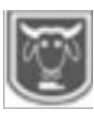 \\ Abstract \\ Federal University of Technology, P.M.B. 704, Akure, Nigeria. \\ *Corresponding author: alaladeja16@gmail.com
}

Lablab purpureus is a perennial legume, is a valuable feed resource for livestock production. The foliage of three cultivars of Lablab purpureus (Tln-43, Tln-49 and Tln-51) were evaluated for their proximate, minerals compositions and anti- nutritional factors in a completely randomized block design experiment. Results showed significant differences among cultivars in $(P<0.05)$ crude protein $(16.97 \%)$, ether extract $(5.9 \% E E)$ crude fat (27.37\% CF), ash (9.98\%) and dry matter $(72.44 \%)$ contents. Similarly, minerals contents of phosphorus $(0.37 \% \mathrm{P})$, potassium $0.89 \% \mathrm{~K})$, calcium $(0.26 \% \mathrm{Ca})$, magnesium $(0.29 \% \mathrm{Mg})$, iron $(192.60 \mathrm{mg} / \mathrm{kg} \mathrm{Fe})$, and Zinc $(55.28 \mathrm{mg} / \mathrm{kg} \mathrm{Zn})$ were influenced by cultivars of Lablab purpureus. The values of anti-nutritional factors in the three cultivars of Lablab purpureus leaves ranged from 0.44 to $0.73 \%$ for Saponin, Oxalate (0.40-0.53\%), Phytate(0.62 to $0.85 \%)$, tannin(0.04-0.06\%), trypsin inhibitor (20.24-21.78mg/g)and HCN (1.65$2.37 \mathrm{mg} / \mathrm{g}$ ). It was concluded from this study that, nutrient contents, anti-nutrient factors as well as mineral contents were influenced by cultivars of purpureus, though their antinutrients contents cannot poses any deleterious effect to ruminant animal's feed and feeding regime.

Keywords: Proximate, Minerals compositions, Anti-nutritional contents, Lablab purpureus leaves.

\section{Introduction}

Lablab purpureus is a climbing annual or short-live perennial with long stems. It is a valuable feed resource for livestock production. It is a leguminous plant that can be grazed by both large and small ruminant animals (Muhammed et al., 2004). Its hay is palatable as well as being used for making good silage. Forages are known to have an important role in the nutrition of ruminant animals in terms of providing energy, protein and mineral element for chewing and rumination (Ahmad et al., 2000). The importance is under scored by the fact that a major constraint to livestock production in tropical Africa is the scarcity and fluctuating quality of year round forage supply (Ajayi et al., 2005).

Furthermore, most available ruminant feeds and feedstuff during the dry season have been described as fibrous, resulting in low digestibility and poor livestock production (Richard et al., 1994). The use of forage legume such as lablab as feed supplements has been shown to enhance the intake of poor roughages, improve growth rates and increase production efficiency in ruminants (Orden et al., 2000). Suitable legumes species have the potential to ameliorate feed constraints, especially for cattle and other 
ruminants, during the dry season, through their higher nutritive value relative to natural fallows (Minson, 1990). Among the many introduced forage legumes that have so far been evaluated in Nigeria, lablab has been reported to be a promising crop for the Northern guinea savannah (Thomas and Sumberg, 1995. Wuafor and Odunze, 1999). The foliage analysis result suggests that it had high protein content (15-30\%) as well as high levels of lysine and digestibility (Valenzuela and Smith, 2002). The hay is high in crude protein $(>17 \%)$. Ash (8\%) and digestibility (>54\%) (Murungweni et al., 2004).

Lablab purpureus plays an important role in the development of drought resistance mechanisms (Subbarao et al., 1995). These mechanisms include the ability of lablab to grow deep tap roots enabling the plant to reach deep residual soil moisture (Smart 1996). Lablab was considered to cope better with drought conditions compared to some of the more widely grown legumes such as common bean(Phaseolus vulgaris) or cowpea(Vigna unguiculata), moreover lablab is a traditional food and fodder crops in Africa and offer great potential for small holder farmer systems in the semi-arid region.(Karachi, 1997 and Osman, 2007).

Among the introduced forage legumes that have so far been evaluated in Nigeria, lablab have been reported to be a promising crop for its characteristics of possessing high protein content, high level of lysine and digestibility. Also it enhances intake of poor quality roughages, improves growth rate, and also increase production efficiency in ruminants. This study is to access different cultivars of Lablab purpureus leaves to know the cultivar that possess the best characteristics among others. There is need for farmers to identify the most nutritive and the one with less anti nutrient factors in other to be useful for ruminant animals as feed and the one that is considered most preferred among the hosted cultivars.

\section{Materials and methods Experimental site}

The experiment was carried out at Teaching and Research farm of Oyo State College of Agriculture and Technology, Igboora which is located within $7^{0} 15$ North and $3^{0} 30$ East of the equator with an average annual temperature $27^{\circ}$ (Sanusi, 2011).

Experimental layout and management practices

The area of land used was $144 \mathrm{~m}^{2}$. The land was cleared, stumped and leveled manually to obtain a clean seed bed. The experimental plots were laid in randomized complete block design. Each experimental plot measured $3 \mathrm{~m} \times 3 \mathrm{~m}$ with $1 \mathrm{~m}$ gap between plots. There were three treatments which consist of three (3) different cultivars of Lablab purpureus were Tln-43, Tln-49 and Tln-51 respectively. Each treatment was replicated thrice and seeds of three of Lablab purpureus were procured from the International Institute of Tropical Agriculture (IITA), Ibadan, Oyo State, Nigeria. Treated seed of Lablab purpureus were planted at rated of 2 seed per hole with a spacing of $50 \mathrm{~cm} \times 50 \mathrm{~cm}$. Before flowering 10 weeks age the herbage sample was taken from three replications pooled and mixed, one representative sub sample was taken per accession and saved pending chemical analysis after drying.

\section{Proximate composition}

The air-dried leaves were ground into fine powder. About $10.0 \mathrm{~g}$ of the grounded leaves was exhaustively processed for various parameters according to the Association of Official Analytical Chemists methods; (AOAC, 1990; AOCS, 2000). The proximate analysis (fats, crude protein, moisture, crude fiber and ash) of the leaves 
were determined using AOAC methods. Using weight difference, moisture and ash were obtained. The fiber content was estimated from the loss in weight of crucible and its content on ignition. The nitrogen value, which is the precursor for protein of a substance, was determined by micro kjeldah method, involving digestion, distillation and finally titration of the sample (AOCS, 2000). The nitrogen value was converted to protein by multiplying with a factor of 6.25 . The determination of crude lipids content of the samples was done using soxhlet type of direct solvent extraction method. The solvent used was petroleum ether (boiling range $40-60^{\circ} \mathrm{C}$ ). The result of proximate value was all estimated as percentage (AOAC, 1990; AOCS, 2000).

\section{Mineral analysis}

The mineral elements were analyzed using the method of Walinga et al. (1989); the elements in the samples were brought into solution by wet digestion technique using a mixture of concentrated nitric, prechloric and sulphuric acid. In the ratio 9:2:1 respectively. $\mathrm{K}, \mathrm{Fe}, \mathrm{Zn}, \mathrm{Ca}$, and $\mathrm{Mg}$ were determined by atomic absorption spectrometer and phosphorus was determined by using Vanadomolybdate Calorimetric Method (AOAC, 1995).

\section{Anti-nutritionalfactor}

Oxalate was determined by the method of Krishna and Ranjina, (1980) while phytate was determined by AOAC, (1990) method. The tannin was determined by the procedure of (Polshettiwar et al., 2007). Trypsin inhibitor activity was determined according to the method of Kakade et al. (1974).

\section{Statistical analysis}

Data obtained were subjected to analysis of variance using General linear model of SAS, 2000. The significant means were separated using Duncan multiple range test.

\section{Results and discussions Results}

Table 1 shows the proximate composition of three cultivars of Lablab purpureus foliage. There were significant differences $(\mathrm{P}<0.05)$ among the three accessions in proximate composition of their leaves. The three cultivars of Lablab purpureus were Tln-43, Tln-49 and Tln-51 respectively. The Crude protein $(\mathrm{CP} \%)$ contents of three cultivars of Lablab purpureus ranged from Tln-51 (14.88\%) to Tln-43 (16.97\%). The concentration of Ether extract (EE \%) ranged from $2.65 \%-3.09 \%$ and the highest value for ether extract was noted in Tln-49 $(3.09 \%)$ leaves while the least was observed in Tln-51(2.65\%). Crude fibre (CF \%) was varied among the three cultivars of Lablab purpureus and it ranged from $17.18 \%$ to $27.35 \%$. Highest crude fibre content was observed in Tln-51 $(27.35 \%)$ and the least value was noted in Tln-49 (17.18\%). The concentration of Dry matter content among the three cultivars of Lablab purpureus varied from $66.90 \%$ to $72.44 \%$. The highest value of dry matter was noted in Tln-51 (72.44\%) while least value was obtained in Tln-49 (66.90\%). There was no difference among cultivars with regards to ash content, but it was numerically higher in Tln-51 (9.95\%).

Table 1: Proximate composition of three cultivars of Lablab purpureus leaves

\begin{tabular}{llllll}
\hline Parameters & CP & EE & CF & Ash & DM \\
\hline Lablab purpureus (Tln-49) & $15.67^{\mathrm{b}}$ & $3.09^{\mathrm{a}}$ & $17.18^{\mathrm{b}}$ & 9.87 & $66.90^{\mathrm{c}}$ \\
Lablab purpureus (Tln-51) & $14.88^{\mathrm{c}}$ & $2.65^{\mathrm{b}}$ & $27.35^{\mathrm{a}}$ & 9.95 & $72.44^{\mathrm{a}}$ \\
Lablab purpureus (Tln-43) & $16.97^{\mathrm{a}}$ & $3.07^{\mathrm{a}}$ & $21.69^{\mathrm{c}}$ & 9.65 & $71.10^{\mathrm{b}}$ \\
SEM & 0.18 & 0.04 & 0.73 & 0.12 & 0.45 \\
\hline abc Means with different superscripts along the same row are significant $(\mathbf{P}<\mathbf{0 . 0 5})$ different
\end{tabular}


Three cultivars of Lablab purpureus foliage in Igbo-Ora, Oyo State, Nigeria are nutritive

Results of the mineral contents of the cultivars are presented in Table 2. Significant $(\mathrm{P}<0.05)$ difference were observed among the three cultivars in terms of mineral contents. The concentration of phosphorus $(\mathrm{P} \%)$ among the three cultivars of Lablab purpureus leaves was the same numerically $(0.37 \%)$. The concentration of potassium $(\mathrm{K} \%)$ contents varied and their values ranged from $0.86 \%$ to $0.89 \%$ among the three cultivars of Tln-49, Tln-51, and Tln-43 respectively. The highest value of potassium was noted in Tln-43 (0.89\%) while the least value was noted in Tln-51
$(0.86 \%)$. Calcium contents varied among the three cultivars from $0.24 \%$ to $0.26 \%$. Highest Calcium content was observed in Tln-49 $(0.26 \%)$ while least value was noted in Tln-43 $(0.24 \%)$. The highest values for iron $(192.60 \mathrm{mg} / \mathrm{kg})$ and zinc $(55.28 \mathrm{mg} / \mathrm{kg})$ were obtained in Tln- 49 followed by Tln-43 on iron $(191.60 \mathrm{mg} / \mathrm{kg})$ and zinc $(53.58 \mathrm{mg} / \mathrm{kg})$, the least value obtained in Tln-51 for iron $(190.80 \mathrm{mg} / \mathrm{kg})$ and zinc $(52.73 \mathrm{mg} / \mathrm{kg})$. The concentration of magnesium $(\mathrm{Mg} \%)$ among the cultivars of Lablab purpureus varied from $0.28 \%$ to $0.29 \%$. Comparable value $(0.29 \%)$ was observed in both Tln-43 and Tln-51.

Table 2: mineral composition of three cultivars of Lablab purpureus foliage

\begin{tabular}{lllllll}
\hline Parameters & $\mathrm{P} \%$ & $\mathrm{~K} \%$ & $\mathrm{Ca} \%$ & $\mathrm{Mg} \%$ & $\mathrm{Fe}(\mathrm{mg} / \mathrm{kg})$ & $\mathrm{Zn}(\mathrm{mg} / \mathrm{kg})$ \\
\hline Lablab purpureus $(\mathrm{Tln}-49)$ & 0.37 & $0.88^{\mathrm{b}}$ & $0.26^{\mathrm{a}}$ & $0.28^{\mathrm{b}}$ & $192.60^{\mathrm{a}}$ & $55.28^{\mathrm{a}}$ \\
Lablab purpureus (Tln-51) & 0.37 & $0.86^{\mathrm{c}}$ & $0.25^{\mathrm{b}}$ & $0.29^{\mathrm{a}}$ & $190.80^{\mathrm{c}}$ & $52.73^{\mathrm{c}}$ \\
Lablab purpureus (Tln-43) & 0.37 & $0.89^{\mathrm{a}}$ & $0.24^{\mathrm{c}}$ & $0.29^{\mathrm{a}}$ & $191.60^{\mathrm{b}}$ & $53.58^{\mathrm{b}}$ \\
SEM & 0.001 & 0.002 & 0.002 & 0.001 & 0.002 & 0.12 \\
\hline abc
\end{tabular}

${ }^{\text {abc }}$ Means with different superscripts along the same row are significant $(\mathbf{P}<0.05)$ different

Table 3: shows the results of anti-nutrient contents present in cultivars of Lablab purpureus leaves. The saponin level of the cultivars ranged from $0.44 \%$ to $0.73 \%$. Highest saponin content $(0.73 \%)$ was noted in Tln-51 followed by Tln-43 $(0.69 \%)$ and least was observed in Tln-49 (0.44\%). Oxalate level in Tln-51 (0.53\%) was the highest compared to Tln-43 $(0.52 \%)$ and Tln-49 $(0.40 \%)$. The phytate level ranged from $0.62 \%$ to $0.85 \%$. Highest phytate content was observed in Tln-51 (0.85\%) and the lowest value in Tln-49 $(0.62 \%)$. The concentrate of tannin among the cultivars varied from $0.04 \%$ to $0.06 \%$. Highest value was observed in Tln-51 (0.06\%) while the least value was noted in Tln-49 (0.04\%). The trypsin inhibitor varied among the three cultivars of Lablab purpureus from $20.24 \mathrm{mg} / \mathrm{kg}$ to $21.78 \mathrm{mg} / \mathrm{g}$ with the highest trypsin inhibitor content noted in Tln-51 $(21.78 \mathrm{mg} / \mathrm{g})$. Lowest value of trypsin inhibitor was however observed in Tln-49 $(20.24 \mathrm{mg} / \mathrm{g})$. The HCN content of the three cultivars examined ranged from $1.65 \mathrm{mg} / \mathrm{g}$ to $2.37 \mathrm{mg} / \mathrm{g}$. Highest $\mathrm{HCN}$ content was observed in Tln-51 $(2.37 \mathrm{mg} / \mathrm{g})$ and least value noted in Tln- $49(1.65 \mathrm{mg} / \mathrm{g})$.

Table 3: Anti-Nutrient Contents Present in Three Accessions of Lablab purpureus

\begin{tabular}{lcccccc}
\hline Parameters & $\begin{array}{l}\text { Saponin } \\
(\%)\end{array}$ & $\begin{array}{l}\text { Oxalate } \\
(\%)\end{array}$ & $\begin{array}{l}\text { Phytate } \\
(\%)\end{array}$ & $\begin{array}{l}\text { Tannin } \\
(\%)\end{array}$ & $\begin{array}{l}\text { Trypsin } \\
\text { Inhibitor } \\
(\mathrm{mg} / \mathrm{g})\end{array}$ & $\begin{array}{l}\text { HCN } \\
(\mathrm{mg} / \mathrm{kg})\end{array}$ \\
\hline Lablab purpureus $(\mathrm{Tln}-49)$ & $0.44^{\mathrm{c}}$ & $0.40^{\mathrm{c}}$ & $0.62^{\mathrm{c}}$ & $0.04^{\mathrm{c}}$ & $20.24^{\mathrm{c}}$ & $1.65^{\mathrm{c}}$ \\
Lablab purpureus $($ Tln-51) & $0.73^{\mathrm{a}}$ & $0.53^{\mathrm{a}}$ & $0.85^{\mathrm{a}}$ & $0.06^{\mathrm{a}}$ & $21.78^{\mathrm{a}}$ & $2.37^{\mathrm{a}}$ \\
Lablab purpureus $($ Tln-43) & $0.69^{\mathrm{b}}$ & $0.52^{\mathrm{b}}$ & $0.84^{\mathrm{b}}$ & $0.05^{\mathrm{b}}$ & $21.69^{\mathrm{b}}$ & $1.74^{\mathrm{b}}$ \\
SEM & 0.02 & 0.01 & 0.02 & 0.001 & 0.02 & 0.19 \\
\hline abc
\end{tabular}




\section{Alalade, Akinlade, Fajemisin and Adebisi}

\section{Discussion}

Proximate composition of three cultivars of Lablab purpureus foliage

The percentage crude protein ranged (14.88-16.97\%) was recorded for three cultivars of Lablab purpureus. The CP contents of all the cultivars were high and well above the $15 \%$ level considered adequate for lactating and growth in dairy cows (Omokanye, 2001). The higher values of crude protein recorded for the three cultivars of Lablab purpureus in the present study was higher than $7 \% \mathrm{CP}$ requirement for ruminant animals which will provide ammonia requirement by the rumen microorganism to support optimum microbial activity. The foliage could serve as potential protein supplement and enhance the feed intake and utilization of low quality grass and fibrous crop residues by ruminants. The importance of protein to animal and human health cannot be over emphasized; therefore Lablab purpureus foliage could be used as feed protein supplement. Ether extract contents of three cultivars of Lablab purpureus ranged (2.65-3.09\%). The value recorded for ether extract in the present study fell below $4.10 \%$ reported by Alalade et al., (2016) for Psophocarpus tetragonolobus leaves. The Ether extract contents of all cultivars fell within the range of (4-10\%) EE reported by Campbell et al., (2006). The value of ether extract in the all cultivars was an indicator of higher energy level in the cultivars for the animal (Babayemi and Bamikole, 2006) and thus, this was a major form of energy stored in plant which will be utilized by animals for body maintenance and production. The crude fiber content of three cultivars of Lablab purpureus foliage ranged from (17.18-25.35\%) which was higher compared with $14.80 \%$ of Mucunautilis leaves reported by Ujowundu et al., (2010) but below (23.8\%) for Stylosanthes hamata
(Akinlade et al., 2004). The crude fiber contents of all cultivars fell within the (15$20 \%$ ) recommended for improved intake and production in finishing ruminant (Buxton, 1996). The crude fiber content value of all cultivars of Lablab purpureus leaves reported will aid digestion and absorption of water in favour of animals (Ayoola and Adeyeye, 2000). The highest value of $9.95 \%$ ash content in the cultivars of Lablab purpureus was above (5.08\%) recorded for Psophocarpus tetragonolobus leaves (Alalade et al., 2016) and also higher than $(3.70 \%)$ reported for Mucuna utilis leaves (Ujuwund uet al., 2010).

Mineral composition of three cultivars of Lablab purpureus foliage

The mineral contents of all cultivars gave the idea of possibility using the plant as a complete diet for ruminant animals. The phosphorus content of all cultivars of Lablab purpureus leaves $(0.38 \%)$ were higher compared to NRC recommended $0.15 \%$ for phosphorus (NRC, 1985). The level of phosphorus in all cultivars of Lablab purpureus leaves was consistently above the $0.2 \%$ level which could satisfy livestock dietary maintenance requirement (NRC, 1985). Phosphorus plays an important role in carbohydrate, lipid, and amino acid and metabolism. Phosphorus is required for blood coagulation (Thromboplastin) satisfactory bone calcification, optimum grow rate and optimum utilization of both calcium and phosphorus (Underwood, 1981).

The calcium $(0.26 \%)$ content of all cultivars of Lablab purpureus leaves was higher than $(0.09 \%)$ observed in Canavaliaensiformis leaves by Akinlade $e t$ al. (2007). The $\mathrm{Ca}$ values found in this study were considered adequate for the optimum performance of ruminants. The value of Calcium of the Lablab purpureus leaves would not meet the theoretical 


\section{Three cultivars of Lablab purpureus foliage in Igbo-Ora, Oyo State, Nigeria are nutritive}

Calcium requirement of $0.30 \%$ recommended in diet ruminants (ARC, 1980) Calcium helps in the regulation of muscle and in the development of kid weaners and foetus in bones and teeth development (Margaret and Vickery, 1997).

The magnesium least content of three cultivars of Lablab purpureus leaves $(0.28 \%)$ was higher than $0.20 \%$ reported for Canavaliaensiformis leaves by Akinlade et al. (2007). The higher Mg level $(0.29 \%)$ found in this study was higher than $0.12 \%$ to $0.20 \%$ of the requirement of the ruminant's diet suggested by (NRC, 1985). Magnesium is an important mineral element in connection with its role in circulatory disease such as ischaemic heart disease and calcium metabolism (Ishida $e t$ al., 2000).

The Iron content of all cultivars of Lablab purpureus ranged $(190.80-192.60 \mathrm{mg} / \mathrm{kg}$ ) and was higher compared to (181.65 $\mathrm{mg} / \mathrm{kg}$ ) reported for Iron content of Psophocarpus tetragonolobus leaves (Alalade et al., 2016). Accessions of Lablab purpureus leaves content in the present study was above $(50 \mathrm{mg} / \mathrm{kg})$ considered sufficient for the requirement of ruminant animals for optimal performance and also above the critical levels of $\mathrm{Fe}$ in animal tissue $(30-50 \mathrm{mg} / \mathrm{kg}$ ) (Khan et al., 2005). This implies that foliage of these cultivars were good sources of dietary iron. Iron is said to be an important element in the diets of pregnant animals, nursing animals, infant and other related disease (Anonymous, 1980).

The concentration of zinc in the plant forage samples was found to be (53.40$54.76 \mathrm{mg} / \mathrm{kg})$ and was higher than (44.3 $\mathrm{mg} / \mathrm{kg}$ ) recorded for Clitoria ternatea leaves by Swati and Varsha (2014). It has been suggested that $30 \mathrm{mg} / \mathrm{kg}$ zinc is a critical dietary level although it has been recommended that concentration of 12-20 $\mathrm{mg} / \mathrm{kg}$ are adequate for growing ruminants (Melaku et al., 2005). Zinc is said to be an essential trace element for protein and nucleic acid synthesis and normal body development during period of rapid growth such as infancy and recovery from illness (Barry, 1984).

Anti-nutrient content present in three cultivars of Lablab purpureus leaves

This tannin level was much lower than the level of 5\% at which goats may reject feed (McLeod, 1974). Tannin at this level protects liable plant protein in the rumen and consequently increases the supply of high quality protein in to the duodenum (McLeod, 1974). However, when forage legumes contain high level of condensed tannins, intake and apparent digestion of protein and carbohydrate are depressed (Bamikole et al., 2004).

Oxalate in this present study was low (0.40$0.53 \%$ ). It was been reported that $20 \mathrm{~g} / \mathrm{kg}$ oxalate can be lethal to chicken (Acamovic et al., 2004). Oxalate has been shown to depleted the calcium reserve, but these browse species were found to contain responsibly amount of calcium, magnesium and phosphorus (Akinsoyinu and Onwuka, 1988). Calcium and carbon are also released from hydrolysis of calcium oxalate some of which will be either absorbed or excreted by the ruminant animals. With calcium absorption rate of ruminant put at $31 \%$ (Haenlein, 1987) and $\mathrm{P}$ at $4 \%$ absorption (Adeloye and Akinsoyinu, 1985) reasonable amount of the calcium and phosphorus intake will be lost via feaces and urine to the soil.

The saponin value ranged from $0.44 \%$ $0.73 \%$. Feedstuffs containing saponin had been shown to be defaunating agents (Teferedegne, 2000) and capable of reducing methane production (Babayemi $e t$ al., 2004b). Cheeke (1971) reported that 
saponin have effect on erythrocyte haemlysis, reduction of blood and liver cholesterol, depression of growth rate, bloat (ruminant) inhibition of smooth muscle activity, enzyme inhibition and reduction in nutrient absorption. Saponin have been reported to alter cell wall permeability and therefore to produce some toxic effect when ingested (Belmar et al., 1999).

The phytate contents of Lablab purpureus is shown in table 3 . The values range was $(0.62-0.85 \%)$. However, the value was lower than $25 \mathrm{mg} / 100 \mathrm{~g}$ reported by Amata (2010) for leaves of Myrianthus arboreus. The negative effect of phytate in nutrition is the chelating of certain essential element such as $\mathrm{Ca}, \mathrm{Fe}, \mathrm{Mg}$ and Zinc and this contribute to mineral deficiency in people who relies on some food rich in phytate for their mineral intake (Hurrell, 2003). Nevertheless, phytate are considered as phytonutrient providing an antioxidant effect and their mineral binding properties prevent colon cancer by reducing oxidative stress in the lumen of the intestinal tract (Volcanic and Shamsuddin, 2003).

The HCN contents of the browse species examined were equally low. The $\mathrm{HCN}$ ranged from $1.65 \mathrm{mg} / \mathrm{kg}-2.37 \mathrm{mg} / \mathrm{kg}$. The lethal dose of HCN for cattle and sheep is $2.0-4.0 \mathrm{mg}$ per $\mathrm{kg}$ body weight. The lethal dose for cyanogens would be 10-20 time greater because the HCN comprised 5-10\% of their molecular weight (Conn, 1979). H0wever, the quality of HCN produced by most of these species is too low to pose major animal health problem (Kumar and D, Mello, 1998). Animals suffering from cyanide toxicity must be immediately treated by injecting of suitable dose of sodium nitrate and sodium thiosulphate (Kumar, 2003). Generally, only plants that produce more than $20 \mathrm{mg} \mathrm{HCN} / 100 \mathrm{~kg}$ fresh weight are considered deleterious (Everest, 1981).
The values of trypsin inhibitor content were 20.24-21.78mg/g for Lablab purpureus leaves. Trypsin inhibitor is protease inhibitor occurring in raw legume seeds. Protease inhibitors are the most commonly encountered class of anti-nutritional factors of plant origin. This trypsin inhibitor has been reported to be partly responsible for the growth retarding property of legumes. The retardation has been attributed to inhibition protein digestion but there is evidence of pancreatic hyperactivity, resulting in increased production of trypsin with consequent loss of lysine and methionine (Donald, 1995). Trypsin inhibitor has been implicated in reducing digestibility of protein and in pancreatic hypertrophy (Liner, 1976).

\section{Conclusion}

The study showed that Lablab purpureus foliage had better nutrient values due to high content of protein and minerals with relatively low levels of anti-nutrient factors which were below the lethal point in ruminant animals. Lablab purpureus foliage can be recommended as a reliable leguminous plant supplement for ruminant animals, thereby alleviating the crisis of poor quality feed and feeding of ruminant animals during the dry season.

\section{References}

Acamovic, T., Steward, C. S. and Pennycott, T. W. 2004. Poison plants and related toxins. Oxford University press, 608pp.

Ahmad, Z., Ghafoor, A. and Ali, A. 2000. Evaluation of three exotic legume species for fodder potential. Pak. J. Biol. Sci., 3: 2079-2081.

Ajayi, D. A., Adeneye, J. A. and Ajayi, F. T. 2005. Intake and nutrition utilization of West Africa Dwarf $\mathrm{g} o$ a $\mathrm{t} \mathrm{s}$ e d $\mathrm{man} \mathrm{g} o$ 
Three cultivars of Lablab purpureus foliage in Igbo-Ora, Oyo State, Nigeria are nutritive

(Magniferaindica), ficus (Ficus thionningii), Gliricidia (Gliricidia sepium), foliages and concentrates to basal diet of guinea grass (Panicum maximum).World $J$. Agri.Sci., 1: 184-189.

Akinlade, J. A., Farinu, G. O., Aderinola, O.A., Ojeleye, T. Y. and Tona, G. O.2004. Nutritive value Of Stylosanthes guianensis and hamate in derived Savannah zone of Nigeria. Science Focus. 2004; 9:145-149

Akinlade, J. A, Farinu G.O, Taiwo A.A, Aderinola O.A, Adebayo T.A, Ojebiyi O.O, Olaniran O.A, 2007.Agronomic and nutritive evaluation of Jack beans (Canavaliaensiformis) for fodder in the derived savannah zone of Nigeria. International Journal of Agricultural Research.2007; 2(12):1059-1063.USA; 1985.

Akinsoyinu, A.O. and Onwuka, C.F.I. 198). Mineral constituents of some brows plants used in ruminant feeding in Southern Nigeria. Nigeria J. Ani. Prod. 15:57-62.

Alalade, J.A., Akinlade, J.A., Aderinola, O.A., Fajemisin, A.N., Muraina, T. O a n d A m o o . T . A 2016. Proximate, Mineral and Antinutrient contents in Psophocarpustetragonolobus $(\mathrm{L})$ DC. (Winged bean) leaves. British Journal of Pharmaceutical Research 10(2):1-72016.

Amata, I.A., 2010. Nutritive value of leaves of Myranthusarboreus: A browse plant. Int. J.Agric. Res., 5:576-581.

Anynomous. 1980. Analytical Method, for a t o m i a b s or ption Spectrophotometry Perkin Elmer Corporation, Nor work,
Cummenticut; 1980.

AOCS, 2000. Official Methods of Analysis (5thEd). American Oil Chemist Society: Washington, DC, USA. 2000.

AOAC.1990. Official methods of analysis (15th ed.). Washington D.C USA. Association of Official Analytical Chemists inch. 400 - 2200Wilson Boalevard, Arlinton Virginia USA, $2, \quad 910-928$. http://dx.doi.org/10.3923/pjn.2009 .1204 .1208

AOAC, 2000.Official Methods of Analysis. $15^{\text {th }}$ Edn., Association of Official analytical Chemists, Washinton, DC.

ARC. 1980. The nutrient requirement of ruminant livestock $4^{\text {th }}$ ed. 73-310. $\mathrm{CAB}$ International. Wallingford; 1980.

Ayoola P.B and Adeyeye A, 2000. Proximate analysis and nutrient evaluation of some Nigerian pawpaw seed varieties. Science Focus. 2000; 14(4):554-558.

Babayemi O.J.and Bamikole M.A. 2006. Some productive and nutritive effects of Tephrosiabrotealata, Te phrosia candida, Leucaenaleucocephala and Gliricidiasepium hay for West Africa Dwarf goats kept on range. Journal of Central European Agriculture. 2006:7(2):323.

Bamikole M.A., Ikhatua U.J., Ajulo M.T., and Oseji, A.C. 2004. Feed utilization potential of West African dwarf goats fed different proportions of Ficusthonningiiand Panicum maximum. Proceedings of the 29th Annual Conference of the Nigerian Society for Animal Production, Sokoto, Nigeria. 2004;29:336-340. 
Barry T.N, Duncan S.J, 1984. The role of condensed tannin in the nutritional value of lotus pedunclatus for sheep voluntary intake.Journal Association of official Analytical Chemist.1984; 65: 496-497.

Belmar, R., Nava-Montero, R., Sandoval-Castro, C. and Menab, J.M. 1999. J a c k be a n (Canavaliaensiformis L.DC) in poultry diets; Anti-nutritional factors and detoxification studies. A. Review. Poultry Sci. J. 55 (1) 37-59.

Buxton D.R, 1996. Quality related characteristics of forage as influence by plant environment and agronomic factors. Anim. Feed sci. Technol. 1996; 59: 37-49.

Campbell Kli, Garforth C, Heffernan C, Morton J, Paterson R, Rymer C, Upton M, 2006.Small stock in development Natural Resources International LTD. Aylesford, Kent, Uk; 2006.

Cheeke, P.R. 1971. Nutritional and Physiological implication Saponins.A Review. Canadian, J. Ani. Sci. 51:621-623.

Deka R.K and Sarka C.R. 1990. Nutrient composition and anti-nutritional factors of lablab L. seeds. Journal of Food Chemistry 38, 239-246.

Duke J.A. 1992. Handbook of Legumes of World Economic Importance, plenum press, New York, 345pp.

Duke J.A. and Ayensu, E.S. 1985 Medicinal plants of China, References Publications Inc., Algonac, Michigan,340 pp.

Everist, S.L. 1981. Poisonouse plant of Autralia. Revised edition. Augus and Robertson, Sydney FAO (1998) Guide to Efficient Plant nutrition Management, FAO,
Rome, 18 pp.

Goering $H$ K and VanSoest P J 1970 Forage Fibre Analysis. Agriculture Handbook No. 379 USDA. Washington, D.C. 19pp. Hamilton R I and Ruth G E O 1968 Bloat on Dolichos lablab .Tropical Grasslands 2:135-136.

Haenlein, G.F.W. 1987. Mineral and Vitamin requirements and deficiencies. In: Santana O.P.Da, Silva, A.G. and Foote, V.C. (eds), Proc. $14^{\text {th }}$ International Conf. on goats vol. 11 Brabsilia, Brazil Pp.1249-1266.

Hurrell, R.F., 2003. Influence of vegetable protein source on trace element and mineral bioavailability. J. Nutri. 133: 2973S-2977S.

Ishida H, Suzuno H, Sugiyama N, Innami S, Todokoro T, Maekawa A. 2000. Nutritional evaluation of chemical component of leaves and stems of sweet potatoes (Ipomoea $b$ a t a t a $s$ poi r). Food Chemistry.2000; 68:359-367

Khan Z.L, Ashraf M, Hussain A, McDowell L.R, 2005. Seasonal variation of trace element in a semi and yield pasture communication in Soil Science and Plant Analysis 2005; 37:1471-1484.

Krishna, G. and Ranjhan, S.K. 1980. Laboratory Manual for Nutrition Research.Vikas Publishing House.PVK.Ltd, Ghaziabad, V.P (India). PP.1

Kumar, R. and D'Mello, J.P.F. 1998. Antinutritional factors in forage legumes. In: tropical legume in animal nutrition D'Mello J.P.F. and Devendra, D. (eds) CAB International Wallingford UK.

Kumar, R. 2003. Anti-nutritive factors, the potential risk of toxicity and 
Three cultivars of Lablab purpureus foliage in Igbo-Ora, Oyo State, Nigeria are nutritive

methods to alleviate them.

Le Houerou, H.N. 1980. Chemical composition and nutritive value of brows plant in tropical W. Africa. In: H.N. Le Houerou (ed), Brows in Africa: Current state of knowledge. ILCA Addis Ababa Ethiopia pp261-289.

Margaret L and Vickery B. 1997. Plant products of tropical Africa. Macmillan in College Ed. London; 1997.

McLeod, M.N, 1974. Plant tannin. Their role in forage quality. Nutrition Abstracts and Reviews 1974; 11: 803-815.

Melaku, U, Clive, E.W, Habtamon, F. 2005. Content of zinc, iron, calcium and their absorption inhibitors in Ethiopia. .Journal of Food Composition Analysis.2005; 18:803-817.

Milford R and Minson D J 1968 The effect of age and method of haymaking on the digestibility and voluntary intake of the forage legumes Dolichos lablab and Vignasinensis. Australian Journal of Experimental Animal Husbandry. 8:409-418.

Minson, D.J., 1990. Forage in Ruminant Nutrition. Academics Press, New York,USA.

Muhammed, I.R., Olorunju,S.A.S.,Hena S.W. and Agishi, E.C. 2004. Forage yield, crude protein, in vitro dry matter digestibility and mineral content of three cultivars of Lablab (Lablab purpureus). J. Anim. Prod.Res., 2:971-975.

Murungweni, C.,O. Mabuku and G.J. Mangawu, 2004. Mucuna, Lablab and paprika Calyx as Substitutes for Commercial Protein Sources Used in Dairy and Pen -Fattening Diets by Smallholder Farmers in
Zimbabwe. In: Tropical Legumes for Suitable Farming system in Southern Africa Australia, Whitebred, A.M. and B.C Pengelly, (Eds.)., ACAIR Proceedings No. 115. Australian Centre for International agricultural research, Canberra, pp: $12^{\text {th }} 6-135$.

NRC. 1985. National Research Council R e c om m e nd ed Di e tary Allowance, National Academy press, Washington D. C.

Omokanye, A.T., 2001. Seed production, herbage residue and crude protein c o $\mathrm{n} \mathrm{t} \mathrm{e} \mathrm{n} \mathrm{t}$ o f Centrosemapubescensin the year of establishment at Shika Nigeria. Tropiculhira 19:176-179.

Orden, E.A., S.A Abdulrazak, E.M. Cruz, M.E. Orden, T. Ichinohe and T. Fujihara, 2000 . LeucaenaleucocephalaandGlirici diasepiumsupplementation in sheep fed with ammonia treated rice straw: Effect on intake, digestibility, miocrobial protein yield and live-weight, changes. Asian-Aust. J. Anim.Sci., 13: 1659-1666.

Osman, M.A. 2007. Effect of Different Processing Methods, of Nutrient Composition, Anti-nutritional factors, and in vitro Protein Digestibility of Dolichos Lablab bean (Lablab purpureus (L) Sweet ) Pakistan Journal Of Nutrition 6 (4): 299-303, 2007.

Polshettiwar, S.A., Ganjiwale, R.O., Wadher, S.J. and Yeole, P.G. 2007. Spectrophotometric estimation of total tannins in some ayurvedic eye drops. Indian $J$. Pharmaceutical Sci.69 (4):574576 
Ranjbar, G.A., 2007. Forage and hay yield performance of different berseem clover (Trifoliumalexandinum L.) genotypes in mazandaran conditions. Asian J. Plant sci., 6: 1006-1011.

Saleem, M.A., Oyetogun, O.M. and Chedda, H.R., 2005. Nutritive value of browse plant in the Sudan Savannah of North-West Nigeria. Nig. Anim. Pro. 6:3-7

Smart, J. 1996. Canavalia gladiata (Jacq) D.C.(Sword bean). Tropical Pulses. Longman GroupLtd, London, Pp 58.

Sanusi,W.A. 2011. Effect of poverty on participation in non- farm activity in Ibarapa local Government Area of Oyo State, Nigeria. IJAART.182.pp86-95

SAS, 2000. Statistical Analysis System (SAS) User's Guide. SAS Institute Inc., North Carolina, USA.

Swati Deshmukh and VarshaJadhav 2014. Bromatological and minerals a $\mathrm{s} s$ e s s m e $\mathrm{n} \mathrm{t}$ o f Clitoriaternatealeaves. International Journal of Pharmacy and Pharmaceutical Sciences.2014;6:3

Teferedegne, B. 2000. New perspective on the use of tropical plant to improve ruminant nutrition.Pro.Nutr. Soc., 59; 209-214.

Ujowundu C.O, Kalu F.N, Emejlu A.A, Okafor O.E, Nkwonta C.G, Nwosunjoku E.C, 2010 . Evaluation of the chemical composition of Mucunautilis leaves used in herbal medicine in South Eastern Nigeria. Africa Journal of pharmacy and pharmacology. 2010; 4(11):811816.
Underwood EJ. 1980. The mineral nutrition of livestock. Commonwealth Agricultural B u r e a u , S lo u g h, England.1981;10.

Valenzuela, H. and J. Smith, 2002. Cooperative Extension Service publication. University of Hawaii at Manao, Honolulu, United States.

Vucenik, I. and A.M. Shamsuddin, 2003. Cancer inhibition by inositol hex phosphate (1p6) and inositol; from laboratory to clinic.J. Nutri. 33: 3778-3784.

Walinga, I., Van-VEAK, V.W. Houba, V.I.G. and Van-derlee. J. J. 1989. Plant Analysis, Procedures (Soil and Plant Analysis, Part 7) Wagenningen Netherland, 18.

Whyte $R$ O, Nilsson-Leissner $G$ and Trumble H C 1953. Legumes in agriculture. Rome Italy FAO pp 272-273.

Wilson G. P. and Murtagh G. J. 1962. Lablab - New forage crop for the north coast. New South Wales Agricultural Gazette. 73:460-462.

Wood I. M. 1983. Lablab bean (Lablabpurpureus) for grain and forage production in the Ord River Irrigation Area. Australian Journal of Experimental Agriculture and Animal Husbandry 23:162-171.

Received: September, 2017 Accepted: 30th November, 2017 